\title{
Annual measured and simulated thermal performance analysis of a hybrid solar district heating plant with flat plate collectors and parabolic trough collectors in series
}

Tian, Zhiyong; Perers, Bengt; Furbo, Simon; Fan, Jianhua

Published in:

Applied Energy

Link to article, DOI:

10.1016/j.apenergy.2017.07.139

Publication date:

2017

Document Version

Peer reviewed version

Link back to DTU Orbit

Citation (APA):

Tian, Z., Perers, B., Furbo, S., \& Fan, J. (2017). Annual measured and simulated thermal performance analysis of a hybrid solar district heating plant with flat plate collectors and parabolic trough collectors in series. Applied Energy, 205, 417-427. https://doi.org/10.1016/j.apenergy.2017.07.139

\section{General rights}

Copyright and moral rights for the publications made accessible in the public portal are retained by the authors and/or other copyright owners and it is a condition of accessing publications that users recognise and abide by the legal requirements associated with these rights.

- Users may download and print one copy of any publication from the public portal for the purpose of private study or research.

- You may not further distribute the material or use it for any profit-making activity or commercial gain

- You may freely distribute the URL identifying the publication in the public portal 


\title{
Annual measured and simulated thermal performance analysis of a hybrid solar district heating plant with flat plate collectors and parabolic trough collectors in series
}

\author{
Zhiyong Tian, Bengt Perers, Simon Furbo, Jianhua Fan \\ Department of Civil Engineering, Technical University of Denmark, Brovej Building 118, Lyngby, 2800, \\ Denmark
}

\begin{abstract}
Flat plate collectors have relatively low efficiency at the typical supply temperatures of district heating networks $\left(70-95^{\circ} \mathrm{C}\right)$. Parabolic trough collectors retain their high efficiency at these temperatures. To maximize the advantages of flat plate collectors and parabolic trough collectors in large solar heating plants for a district heating network, a hybrid solar collector field with $5960 \mathrm{~m}^{2}$ flat plate collectors and $4039 \mathrm{~m}^{2}$ parabolic trough collectors in series was constructed in Taars, Denmark. The design principle is that the flat plate collectors preheat the return water from the district heating network to about $70^{\circ} \mathrm{C}$ and then the parabolic trough collectors would heat the preheated water to the required supply temperature of the district heating network. Annual measured and simulated thermal performances of both the parabolic trough collector field and the flat plate collector field are presented in this paper. The thermal performance of both collector fields with weather data of a Design Reference Year was simulated to have a whole understanding of the application of both collectors under Danish climate conditions as well. These results not only can provide a design basis for this type of hybrid solar district heating plants with flat plate collectors and parabolic trough collectors in the Nordic region, but also introduce a novel design concept of solar district heating plants to other high solar radiation areas.
\end{abstract}

Keywords: solar district heating plants; parabolic trough collectors; flat plate collectors; thermal performance.

\section{Introduction}

Building energy consumption currently accounts for about $40 \%$ of the total society energy consumption in developed countries [1]-[4]. Different energy system configurations were optimized and the results showed that solar collector fields should be included in the energy supply system to achieve both the economic and environmental optimization [5]. Multi-objective optimizations on central solar heating plants with seasonal storage were carried out [6]. The results showed that the central solar heating plant led to significant environmental and economic improvements compared to the use of a conventional natural gas heating system. Overall, solar heating plants for district heating can reduce the fossil energy consumption in the building sector [7].

\subsection{State of the art}

In the early 1980s, the first several large solar collector arrays was built to connected to the district heating works in Sweden. Then the market of large solar heating plants has increased fast in Denmark [8], Germany [9], Austria [10], Spain and Greece [11]. In 2016, 37 large-scale solar thermal systems were installed compared to 21 new installations in 2015 in Europe. Within these installations, 31 systems were installed in Denmark, 1 system in Sweden, 1 system in France and 4 systems in Germany [11] . Moreover the collector area of 5 existing Danish plants was extended in 2016. An online platform was established for almost all the solar heating plants in Denmark [12]. More than 1.3 million $\mathrm{m}^{2}$ solar heating plants were in operation in Denmark by the end of 2016 and 270 thousand $\mathrm{m}^{2}$ solar heating plants are being planned, as shown in Fig.1. Several large solar heating plants have been constructed in Denmark [13], such as in Vojens (70000 m²), Marstal (33360 m²), Gram $\left(44000 \mathrm{~m}^{2}\right)$, Silkeborg $\left(156694 \mathrm{~m}^{2}\right)$, etc. Denmark is the frontrunner not only in Europe but also worldwide for both largescale systems installed as well as capacity installed in solar district heating sector. Denmark is also the only example of a mature and commercial solar district heating market around the world, which can provide references for other places. Solar collectors are the most important components for the large solar district heating plants. Most solar collectors used in the normal solar heating plants are ground mounted flat plate collectors (FPC). 


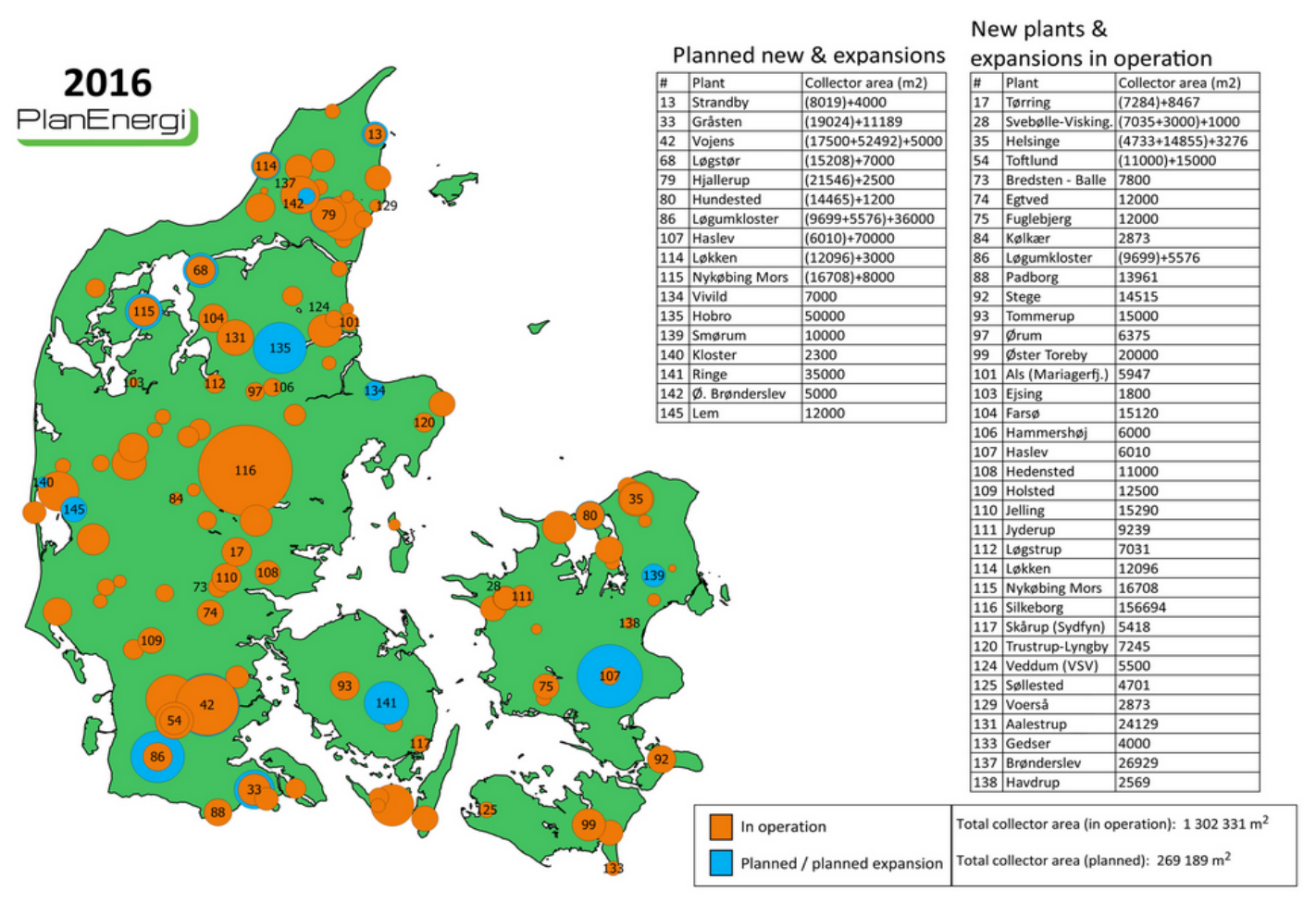

Fig.1.Solar heating plants in Denmark [14].

\subsection{Parabolic trough collectors}

Most parabolic trough collectors (PTC) have previously used to produce electricity. With the requirements of energy conservation in industry, more and more parabolic trough solar collectors have been employed to provide heat for industrial processes in recent years. IEA-SHC TASK 49 [15] has focused on the application of solar collectors in the industry sector. Frank, E. et al., [16] investigated the thermal performances of parabolic trough collectors in two solar heating plants in Swiss dairies and found that the thermal performance of both the solar collector fields could be high under Swiss climate conditions. Silva, R. et al., [17], [18] did simulations and thermo-economic design optimization on parabolic trough collectors for heat production for industrial processes. LCOE (Levelized Cost Of Energy) of $5 \mathrm{c} € / \mathrm{kWh}$ and a PBT (payback time) of 8 years could be achieved at the base scenario conditions considered. Hassine, I. et al., [19] investigated the control strategy of two $1000 \mathrm{~m}^{2}$ solar heating plants (in Austria and Italy). Some design faults of the collector loop controller were found in the first operation period. Based on measurements and simulations with dynamic models, the potential improvements of low-level control algorithms were suggested for the two solar heating plants.

Larcher, M. et al., [20] presented experimental investigations on a parabolic trough collector under development for process heat applications. Results of quasi steady state efficiency measurements on parabolic trough collectors were shown. Kizilkan, O. et al., [21] proposed a parabolic trough solar collector-based integrated system for an ice-cream factory in Turkey and discussed the thermal performance. The payback period of the proposed integrated system was found to be 8.5 years. The payback period was almost the same as reported by Silva, R. [17], [18]. An experimental investigation on a small-sized parabolic trough solar collector for hot water in cold areas was carried out and showed great anti-freezing property of the proposed collector [22]. These investigations show that the application of parabolic trough collectors for high temperature heat production can be economical and feasible if the systems are designed reasonably.

A preliminary case study of parabolic trough collectors for district heating at high latitudes with low solar radiation resources was carried out in 2000 [23]. The economic comparison indicated that parabolic trough systems could be competitive with flat plate collectors, but few practical projects with parabolic trough collectors for district heating were undertaken in the following decades. On the other hand, it is found that most present research of parabolic trough collectors has been on applications with $500 \mathrm{~m}^{2}-1500 \mathrm{~m}^{2}$ collectors for industrial processes [16]-[21] or steam and electricity production [24]-[33]. Limited reports with detailed measurements of the in situ annual thermal performance of large-scale solar heating fields with flat plate collector and parabolic trough collectors for district heating networks are available. 
The operation temperature of solar collectors in solar heating plants in Denmark is in the range from about $40^{\circ} \mathrm{C}$ to $95^{\circ} \mathrm{C}$. The efficiency of flat plate collectors decreases significantly in the range $70^{\circ} \mathrm{C}-95^{\circ} \mathrm{C}$, while parabolic trough collectors maintain relatively high efficiency in this range. To exploit the advantages of both flat plate collectors and parabolic trough collectors in large solar heating plants for district heating networks, a new concept for a hybrid solar heating plant consisting of flat plate collectors and parabolic trough collectors in series has been proposed. The basic principle is that the flat plate collector field preheats the return water from the district heating network from $40^{\circ} \mathrm{C}$ to $70^{\circ} \mathrm{C}$ and then the parabolic trough collector field heats the preheated water from $70^{\circ} \mathrm{C}$ to $95^{\circ} \mathrm{C}$. Feasibility of application of the parabolic trough collector technology in Denmark has been primarily investigated by Aalborg CSP [34] and Technical University of Denmark (DTU) [35] since 2013. 1.3 Scope

A demonstration hybrid solar district heating plant based on the mentioned principle was constructed in Taars of Denmark and put into operation in August, 2015. The hybrid solar heating plant consists of $5960 \mathrm{~m}^{2}$ flat plate collectors and $4039 \mathrm{~m}^{2}$ parabolic trough collector in series. The aim of this work is to demonstrate the application of the hybrid solar heating pant with parabolic trough collectors and introduce a novel design concept for the new solar heating plants. The novelty of this paper is stressed as follows: (1) The studied solar heating plant is the first hybrid large scale solar heating plant $\left(9999 \mathrm{~m}^{2}\right)$ developed for the domestic district heating network in the Nordic area, or even around the world, which integrates the PTC and FPC technologies; (2) Parabolic trough collectors with water as the heat transfer fluid in the novel combined solar heating plant are used to provide hot water for the district heating network, while parabolic trough collectors with oil as the heat transfer fluid are normally used for electricity production; (3) The idea of the hybrid solar heating plant is that the flat plate collectors only work at the low operation temperature level and the parabolic trough collectors work at relatively high temperature level; (4) The integration of parabolic trough collectors can increase the flexibility of the solar heating plants significantly in the whole district heating networks due to the possibility of defocusing; (5) Potential and feasibility of PTC collector in the hybrid solar heating plant under the Danish climate conditions with low solar radiation resource was shown, which can provide a design basis for the development of concentrating solar power technologies in the Nordic area in the near future.

Annual measured and simulated thermal performances with a validated TRNSYS model of the hybrid solar heating plant during its first operation year from September 2015 to August 2016 are shown in this paper. The rest of the paper is organized as follows: the $2^{\text {nd }}$ section introduces the Taars solar heating plant briefly, The $3^{\text {rd }}$ section shows the methods, including measurements and validated TRNSYS in this study. The $4^{\text {th }}$ section presents meteorological data and heat demand. The $5^{\text {th }}$ section presents annual thermal performance of Taars solar heating plant, including both measured and modelled energy output, solar fraction and utilized efficiency. The $6^{\text {th }}$ section shows the typical performance of Taars plant in Design Reference Year and illustrates the potential of the hybrid plant under Danish climate conditions. Finally, the $7^{\text {th }}$ section is the conclusions and future work.

\section{Taars solar heating plant \\ 2.1 Overview}

Figure 2 and 3 show the hybrid solar heating plant with a $5960 \mathrm{~m}^{2}$ flat plate collector field and a $4039 \mathrm{~m}^{2}$ parabolic trough collector field in series in Taars, Denmark (latitude: $57.39^{\circ} \mathrm{N}$, longitude: $10.11^{\circ} \mathrm{E}$, altitute:48m). The plant was put into operation in August, 2015 [34], [35]. Technical data on the solar collector field can be found in Tables 1-2. Figure 4 briefly illustrates the basic principle of the solar heating plant. The solar collector fluid of the parabolic trough collectors is water, while that of FPC is a glycol/water mixture (35\%). The return water from the district heating network is heated up to $65-75^{\circ} \mathrm{C}$ by the heat exchanger connected to the flat plate collector field. Then the preheated water from the flat plate collector field is heated to the required temperature by going through the parabolic trough collector field. The orientation of parabolic trough collectors was $13.4^{\circ}$ towards west from south. The parabolic trough collectors track the sun from east to west when the collectors work during the whole day. There are six rows of parabolic trough collectors and the row distance is $12.6 \mathrm{~m}$. The length of each row parabolic trough collector loop is about $125 \mathrm{~m}$. The orientation of flat plate collectors is south and the collector row distance is $5.67 \mathrm{~m}$. The tilt of the flat plate collectors is $50^{\circ}$. The parabolic trough collectors are delivered by Aalborg CSP A/S. The flat plate collectors consist of two types of the flat plate collectors, namely HTHEATboost 35/10 and HTHEATstore 35/10, manufactured by ArconSunmark A/S [36]. Half of the flat plate collector field is made of HTHEATboost 35/10, while the other half is HTHEATstore 35/10. The backup heat resource consists of two natural gas boilers (9.1 MW in total). Two tanks with a total volume of $2430 \mathrm{~m}^{3}$ are used as heat storage for several days in the summer. 


\subsection{Control strategy}

The plant is oversized for the heat demand in the summer months. To avoid overheating issues in the summer, the parabolic trough collectors are sometimes put out of focus. Feed forward control is used to keep a constant outlet temperature by the flow control in the parabolic trough collector field.

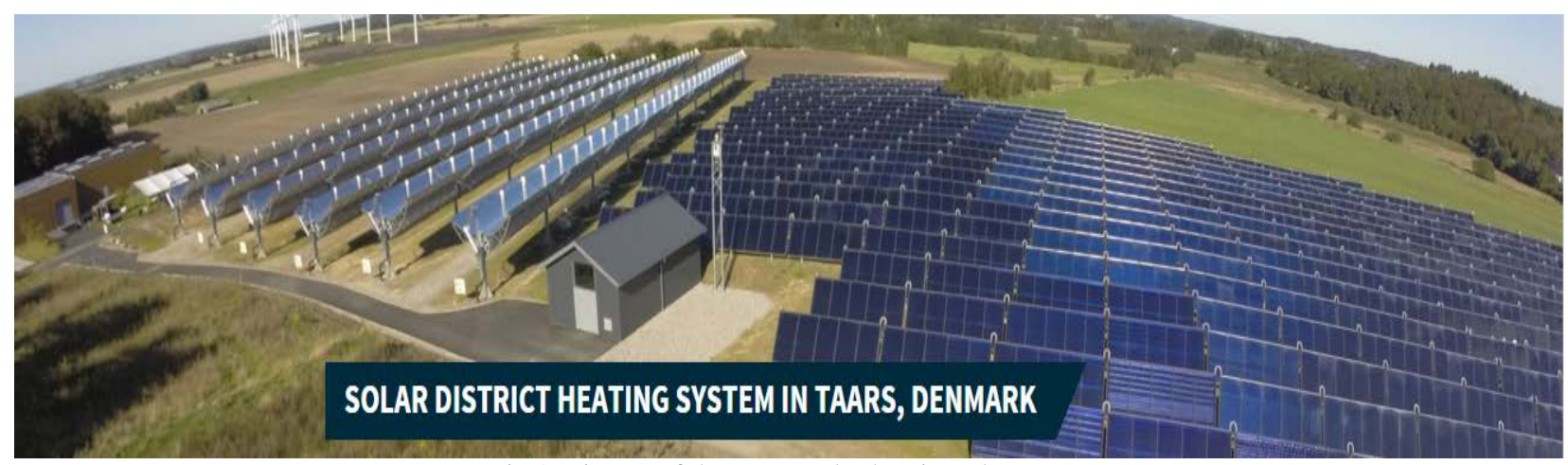

Fig.2. Picture of the Taars solar heating plant.

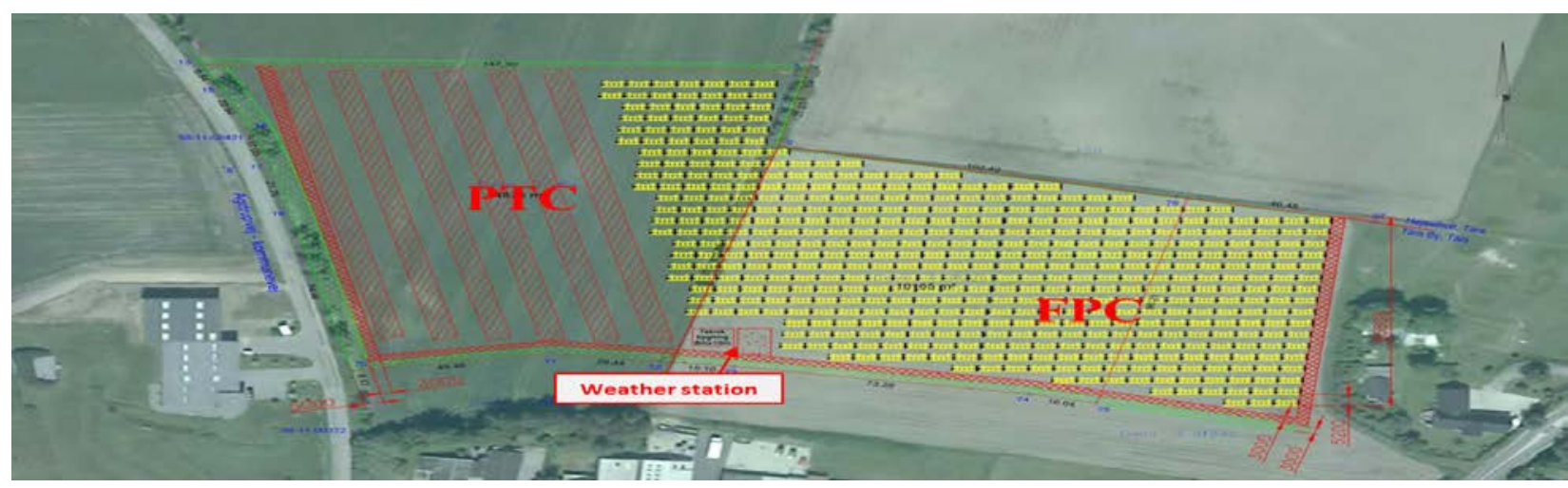

Fig.3. Layout of the solar collector field. 
FPC: $5960 \mathrm{~m}^{2}$

PTC: $4039 \mathrm{~m}^{2}$

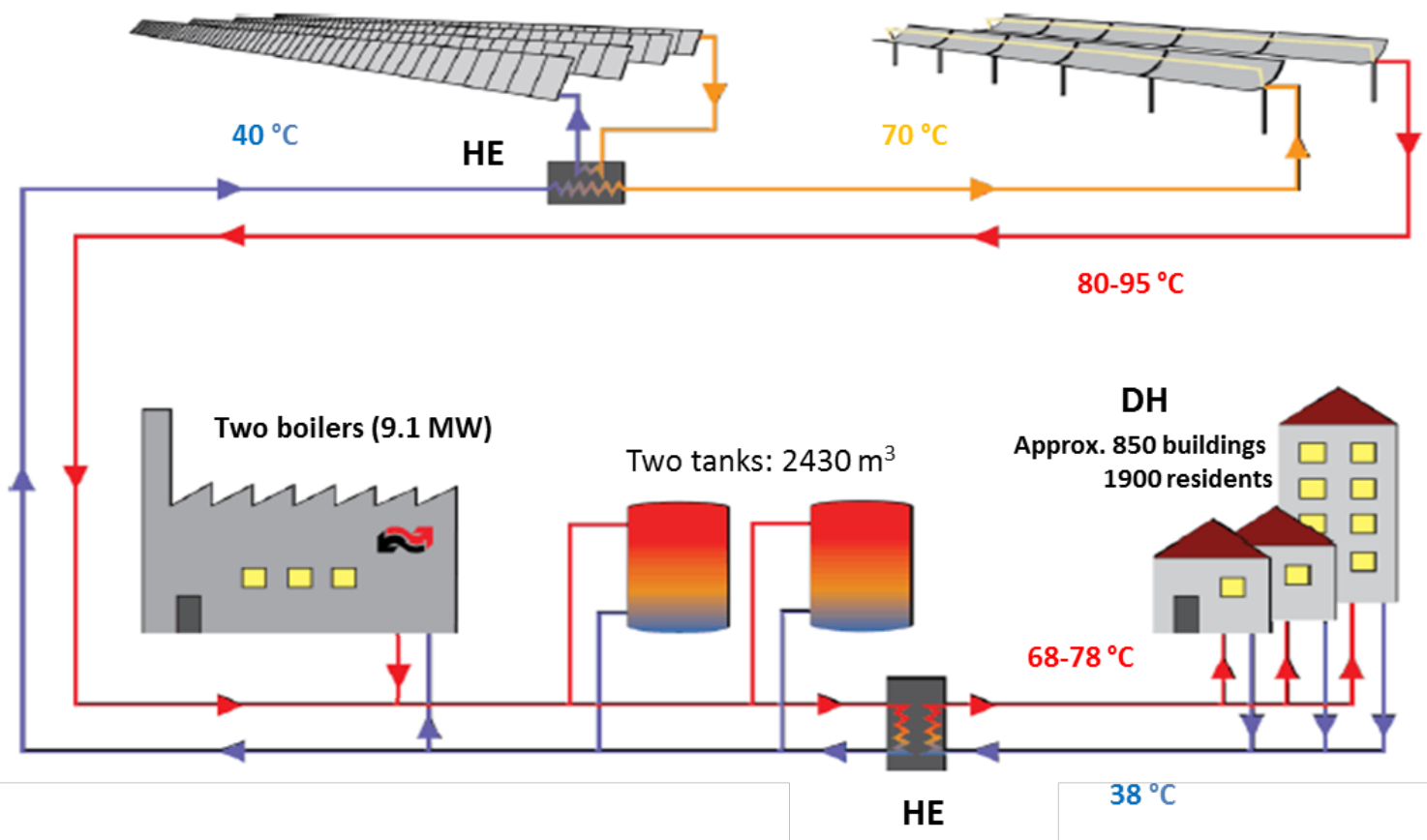

Fig.4. Schematic illustration of the Taars solar heating plant.

Table 1. Parameters of the PTC collector in the Taars plant.

Geometrical parameters for the PTC collector

Absorber tube outer diameter $(\mathrm{m}) \quad 0.070$

Absorber tube inner diameter (m) 0.066

Glass envelope outer diameter (m) $\quad 0.125$

Glass envelope inner diameter (m) $\quad 0.119$

Parabola width (m) $\quad 5.77$

Numbers of modules per row $\quad 10$

Mirror length in each module (m) 12

Geometric concentration ratio $\quad 26.2$

Table 2. Parameters of the FPC collectors in the Taars plant.

\begin{tabular}{ccc}
\hline \multicolumn{2}{c}{ Geometrical parameters for the FP collector } \\
\hline Length, $\mathrm{m}$ & 5.96 \\
Width, $\mathrm{m}$ & 2.27 \\
Thickness, $\mathrm{m}$ & 0.14 \\
Gross area, $\mathrm{m}^{2}$ & 13.57 \\
Aperture area, $\mathrm{m}^{2}$ & & 12.60 \\
Solar collector volume, $\mathrm{L}$ & 10.6 \\
\hline \multirow{2}{*}{ Absorber } & Material & Cu pipe /Al plate \\
& Absorption & 0.95 \\
& Emission & 0.05 \\
\hline \multirow{2}{*}{ Insulation } & Backside & $75 \mathrm{~mm}$ mineral wool \\
& Side & $30 \mathrm{~mm}$ mineral wool \\
\hline Cover(s) & Atireflex glass(AR:3.2mm)-with/without FEP \\
\hline
\end{tabular}




\section{Methods}

The efficiency expressions and the incidence angle modifier of the investigated solar collectors are given by Equations 1-2. The parameters of the parabolic trough collectors based on the aperture area were determined by the Technical University of Denmark [37]. The technical parameters of flat plate collectors based on the gross area were determined by SP Technical Research Institute of Sweden [38], which are available in the reference [39]. The parameters of the investigated solar collectors can be found in Table 3.

$$
\begin{gathered}
\frac{Q}{A}=\eta_{0} K_{\theta b}(\theta) G_{b}+\eta_{0} K_{\theta d}(\theta) G_{d}-c_{1}\left(\mathrm{~T}_{m}-T_{a}\right)-c_{2}\left(\mathrm{~T}_{m}-T_{a}\right)^{2}-c_{3} \frac{d T_{m}}{d t} \text { (eq.01) } \\
K_{\theta b}(\theta)=1-b_{0}\left(\frac{1}{\cos \theta}-1\right)-b_{1}\left(\frac{1}{\cos \theta}-1\right)^{2}, \theta \leq 60^{\circ} \text { (eq.02) }
\end{gathered}
$$

When $\theta>60^{\circ}$, the IAM is linearized from the value at $60^{\circ}$ to a value of zero at $90^{\circ}$.

Table 3. Parameters of the investigated solar collectors.

\begin{tabular}{cccccccc}
\hline$\eta_{0}$ & $\mathrm{~b}_{0}$ & $\mathrm{~b}_{1}$ & $\mathrm{~K}_{\theta \mathrm{d}}$ & $\mathrm{c}_{1},\left[\mathrm{~W} /\left(\mathrm{m}^{2} \cdot \mathrm{K}\right)\right]$ & $\mathrm{c}_{2},\left[\mathrm{~W} /\left(\mathrm{m}^{2} \cdot \mathrm{K}^{2}\right)\right]$ & $\mathrm{c}_{3},\left[\mathrm{~kJ} /\left(\mathrm{m}^{2} \cdot \mathrm{K}\right)\right]$ & \\
\hline 0.779 & 0.1 & 0 & 0.98 & 2.410 & 0.015 & 6.798 & HEATboost 35/10 \\
0.745 & 0.1 & 0 & 0.93 & 2.067 & 0.009 & 7.313 & HEATstore 35/10 \\
0.75 & 0.27 & 0 & 0.038 & 0.04 & 0 & 4 & PTC collector \\
\hline
\end{tabular}

\subsection{Measurements}

The system is well equipped with different accurate sensors and the monitoring data are automatically transferred to the computers. Global solar radiation on the horizontal surface and total radiation on the titled flat plate collectors are measured with Kipp\&Zonen SMP11. DNI is measured with a PMO6-CC pyrheliometer with the sun tracking platform Sunscanner SC1. The inlet and outlet temperatures of the collector fields are measured with SIEMENS TS500 temperature sensors, flow rates of both the FPC field and the PTC field are measured with Sitrans FM MAG3100 P flow meters - SIEMENS. Measured thermal performance is calculated based on the measured parameters.

\subsection{Trnsys model}

A Trnsys model was set up to simulate the thermal performance of both the flat plate collector and the parabolic trough collector field. The TRNSYS model was based on the quasi dynamic method. TRNSYS type 1290 was used to simulate the thermal performance of the collector fields. Type 3b was used as the pump unit in the collector fields. Type $5 b$ was the heat exchanger unit in the FPC field. Type 30 simulated the shadows between the collector rows. Type 4 was used to simulate the tanks. The TRNSYS model was validated by the measurements and was accurate enough to predict the thermal performances of both solar collector fields. Detailed information and validation of the TRNSYS model and uncertainties of measurements are given in [40], [41]. 


\section{Meteorological data and heat demand}

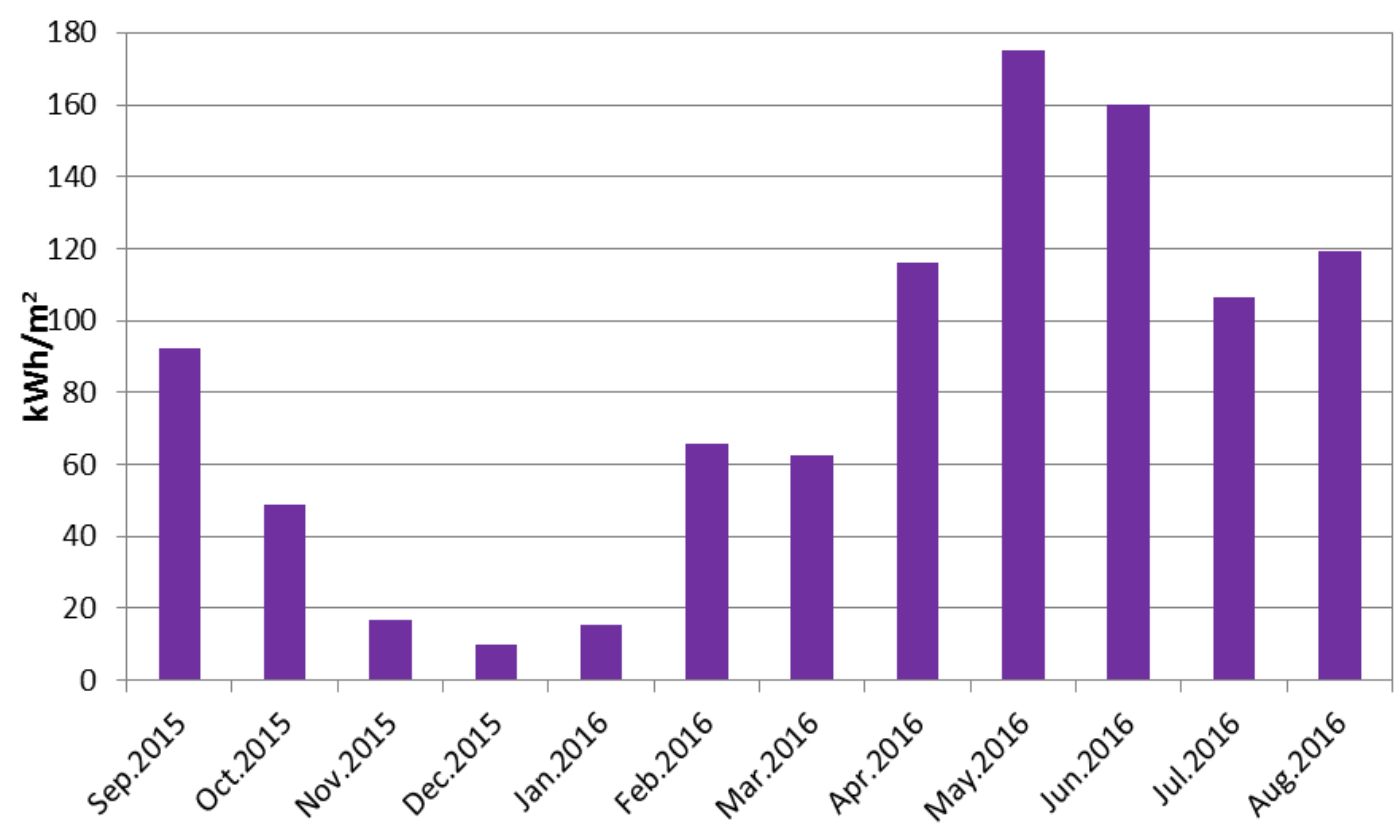

Fig.5. DNI in the Taars solar heating plant (Sep.2015-Aug.2016).

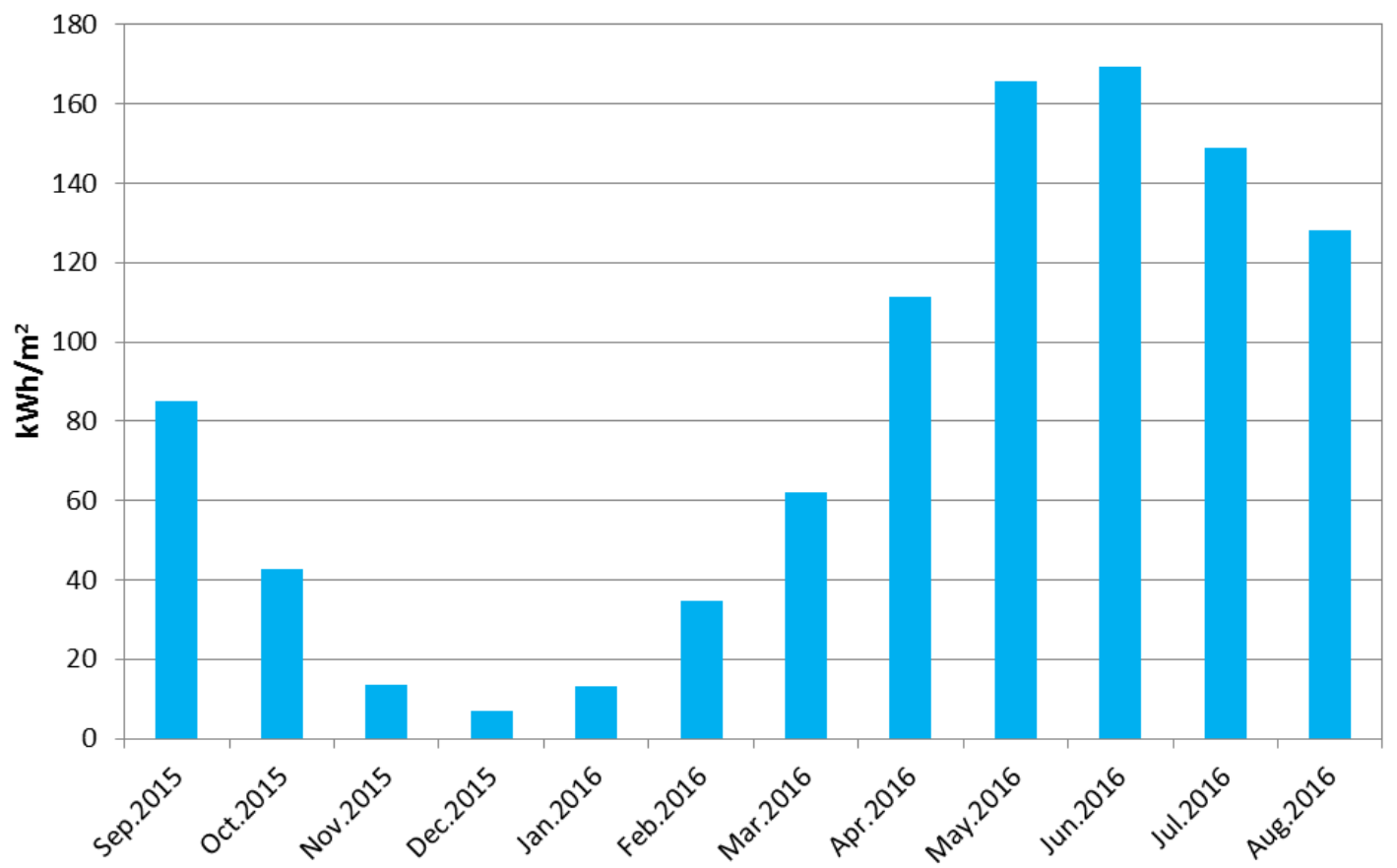

Fig.6. Global radiation on the horizontal surface in the Taars solar heating plant (Sep.2015-Aug.2016). 


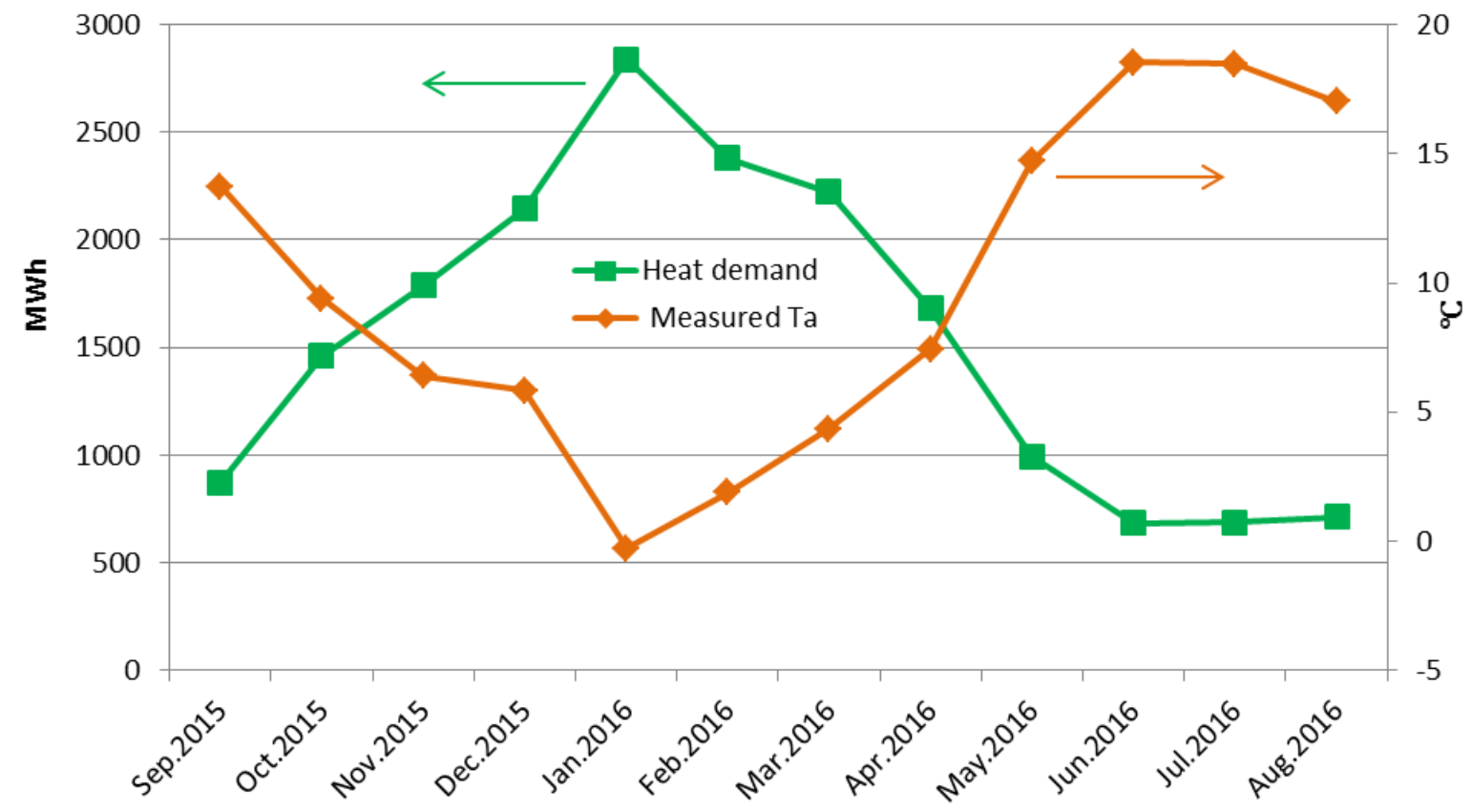

Fig.7. Monthly heat demand and average ambient temperature in the Taars solar heating plant (Sep.2015-Aug.2016).

Figures 5 and 6 show measured monthly DNI and global solar radiation in the Taars heating plant. Obviously, solar radiation from November 1 to January 31 was low in Denmark. Figure 7 shows monthly average ambient temperature from Sep.2015 to Aug.2016 and the heat demand of the Taars district heating network. The average ambient temperature in Jan.2016 was $-0.3^{\circ} \mathrm{C}$, which was the lowest during the studied operation period. The average monthly ambient temperature in both June and July of 2016 was about $18{ }^{\circ} \mathrm{C}$, which was the highest. Table 4 shows the sums of DNI, global radiation on the horizontal surface and heat demand from Sep.2015 to Aug.2016. DNI and global radiation were 990 and $980 \mathrm{kWh} / \mathrm{m}^{2}$ respectively. Heat demand of the Taars district heating network from Sep.2015 to Aug.2016 was 18460 MWh.

Table 4. Sums of DNI, global radiation and heat demand of the Taars solar heating plant (Sep.2015-Aug.2016).

\begin{tabular}{cc} 
Items & Values \\
\hline DNI, $\mathrm{kWh} / \mathrm{m}^{2}$ & 990 \\
Global radiation on the horizontal surface, $\mathrm{kWh} / \mathrm{m}^{2}$ & 980 \\
Heat demand, MWh & 18460 \\
\hline
\end{tabular}

\section{Annual thermal performance}

All the measured and modelled thermal performances given per square meter solar collector field are based on the aperture area of the solar collectors. The time step was 1 minute in the calculations. The inlet temperature and volume flow rate of both the FPC and the PTC collector field in simulation were taken from the measurements.

\subsection{Thermal performance of FPC collectors}




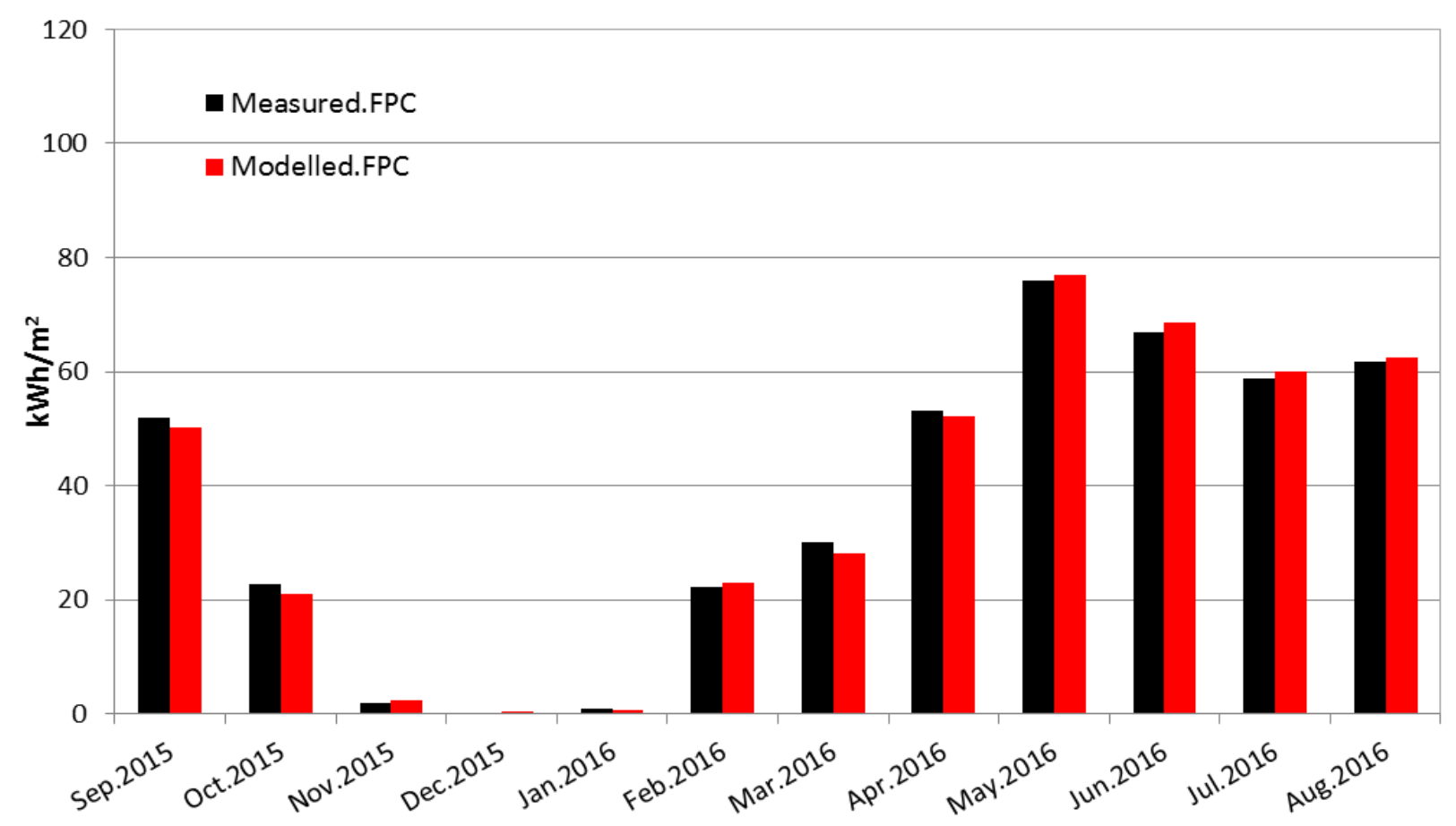

Fig.8. Monthly thermal performance of FPC field (Sep.2015-Aug.2016).

Figure 8 shows monthly measured and modelled thermal performances of the flat plate collector field from Sep.2015 to Aug.2016. The thermal performance of the flat plate collector field was low during the winter because of the low solar radiation. The max monthly thermal performance of the flat plate collector field was higher than $70 \mathrm{kWh} / \mathrm{m}^{2}$ in May, 2016. Both measured and modelled yearly total thermal performances of the flat plate collector field were 2670 MWh for the period Sep.2015 -Aug.2016.

\subsection{Thermal performance of PTC collectors}

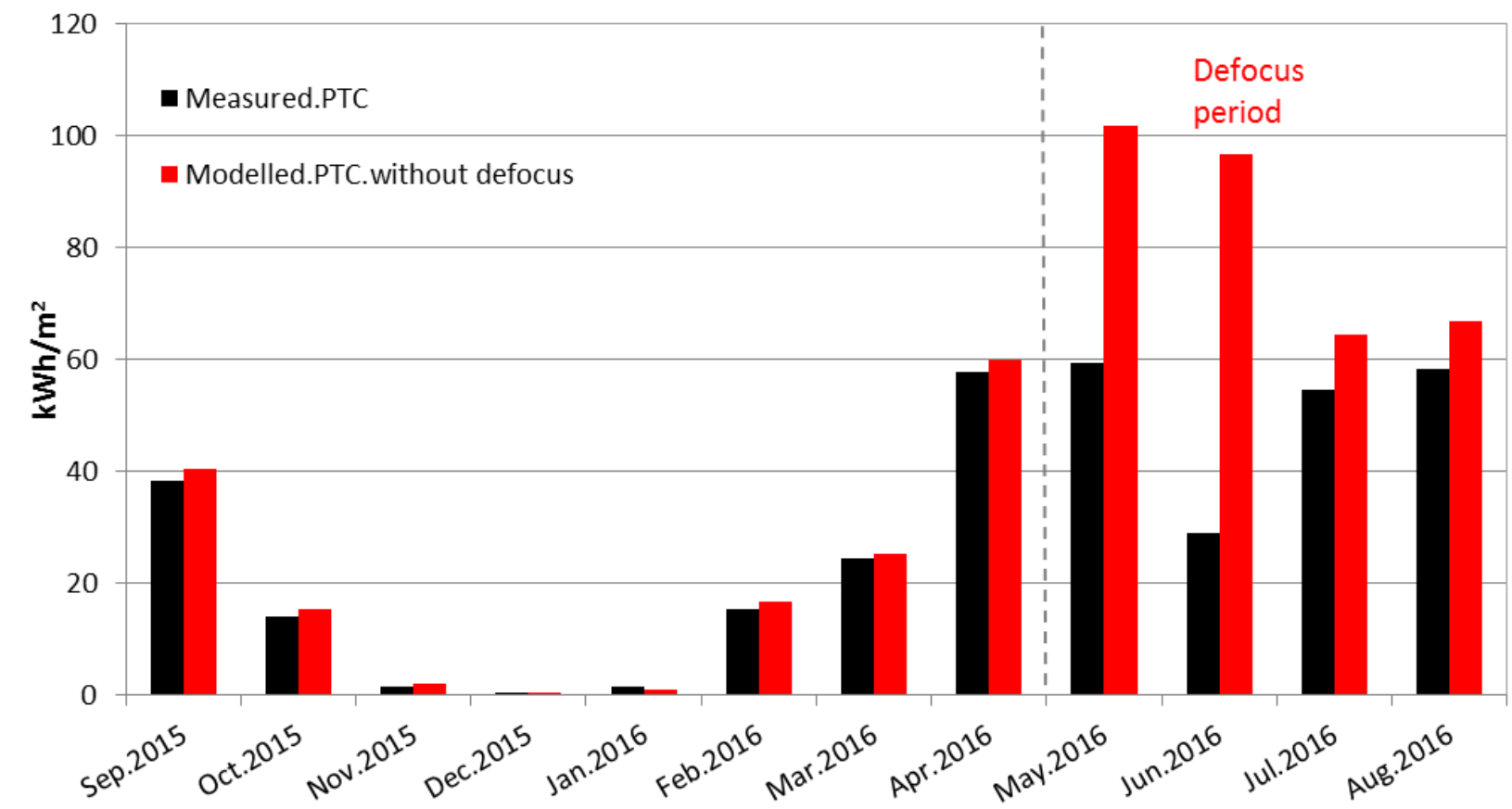

Fig.9. Monthly thermal performance of PTC field. 
As shown in Figure 9, the parabolic trough collector field did not produce much heat during the winter because of low DNI. But in the spring and summer, the parabolic trough collector field performed very well. The parabolic trough collector field should have worked best in the summer, when the solar radiation was high. However, the parabolic trough collector field was defocused sometimes on the sunniest days of summer (such as in May-August) because the flat plate collector field was oversized and the heat demand in the summer was low. The simulated thermal performance in Figure 9 illustrates that the potential monthly thermal performance of the parabolic trough collector field is higher than $90 \mathrm{kWh} / \mathrm{m}^{2} / \mathrm{month}$ if the parabolic trough collector field could continue to operate without defocusing. The measured thermal performance of the parabolic trough collector field for the period September 2015-August 2016 was $354 \mathrm{kWh} / \mathrm{m}^{2}$, while the modelled value with defocus was $359 \mathrm{kWh} / \mathrm{m}^{2}$. The simulated thermal performance of the parabolic trough collector field without defocus was 490 $\mathrm{kWh} / \mathrm{m}^{2}$ for the period Sep.2015-Aug.2016. That is: a reduction of $136 \mathrm{kWh} / \mathrm{m}^{2}$ was calculated due to defocusing of the parabolic trough collector field.

\subsection{Solar fraction}

The Taars district heating network consists of approximate 850 buildings with about 1900 consumers. Measured heat load and total thermal performance of the solar collector fields per collector area from Aug.2015 to Sep.2016 can be found in Figure 10. The solar fraction, defined as the ratio between the solar heat and the heat demand, was very high in the summer when the heat load was low and the weather was sunny, see Figure 11 . As the solar radiation in the winter was low, both the flat plate collector and the parabolic trough collector field produced low quantities of solar heat and the solar fraction in the winter was close to 0 , which is normal for the Nordic area. Table 5 shows a summary of annual thermal performance of the Taars plant. The measured total energy output of the solar heating plant was 4100 MWh and total heat load was 18460 MWh during Sep.2015 to Aug.2016. The solar fraction of the solar heating plant was 22.2\% from Sep.2015 to Aug.2016. As shown in Figure 10 and 11, if the parabolic trough collectors were not defocused, the parabolic trough collectors could have a better thermal performance in the summer. Furthermore, only in June the simulated thermal performance is higher than the heat demand if the parabolic trough collector field was not defocused. By applying large heat storage tanks, the parabolic trough collector field could work normally without defocus in the summer, even in June. In this way solar fraction would have been close to $100 \%$ in the months from May to August. The yearly thermal performance of the combined solar collector field without defocusing of parabolic trough collectors in the summer can reach $4650 \mathrm{MWh}$ and the solar fraction would increase from $22.2 \%$ to 25.2\%. 550 MWh solar heat was lost because of defocusing of parabolic trough collectors in the sunny days in the summer.

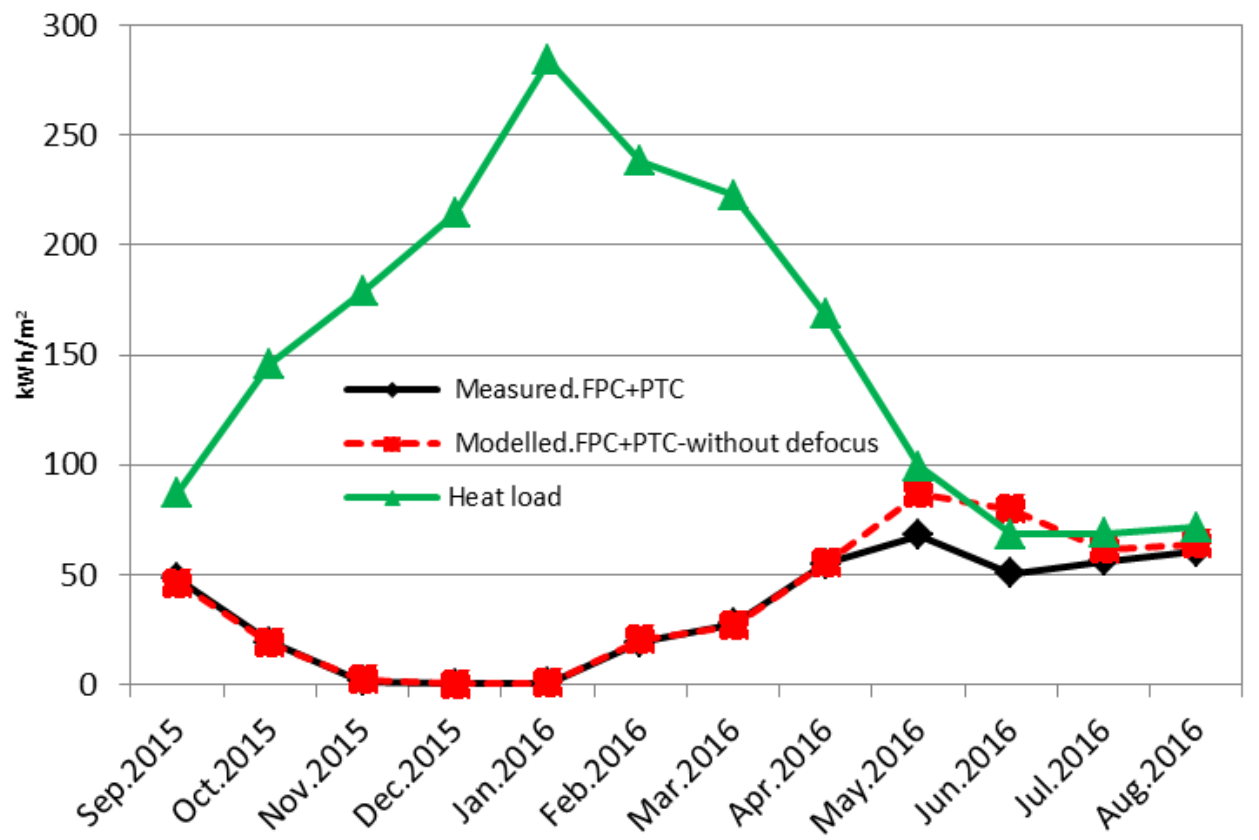

Fig.10. Heat demand and thermal performance of Taars solar heating plant per $\mathrm{m}^{2}$ solar collector aperture area, Sep.2015Aug.2016. 


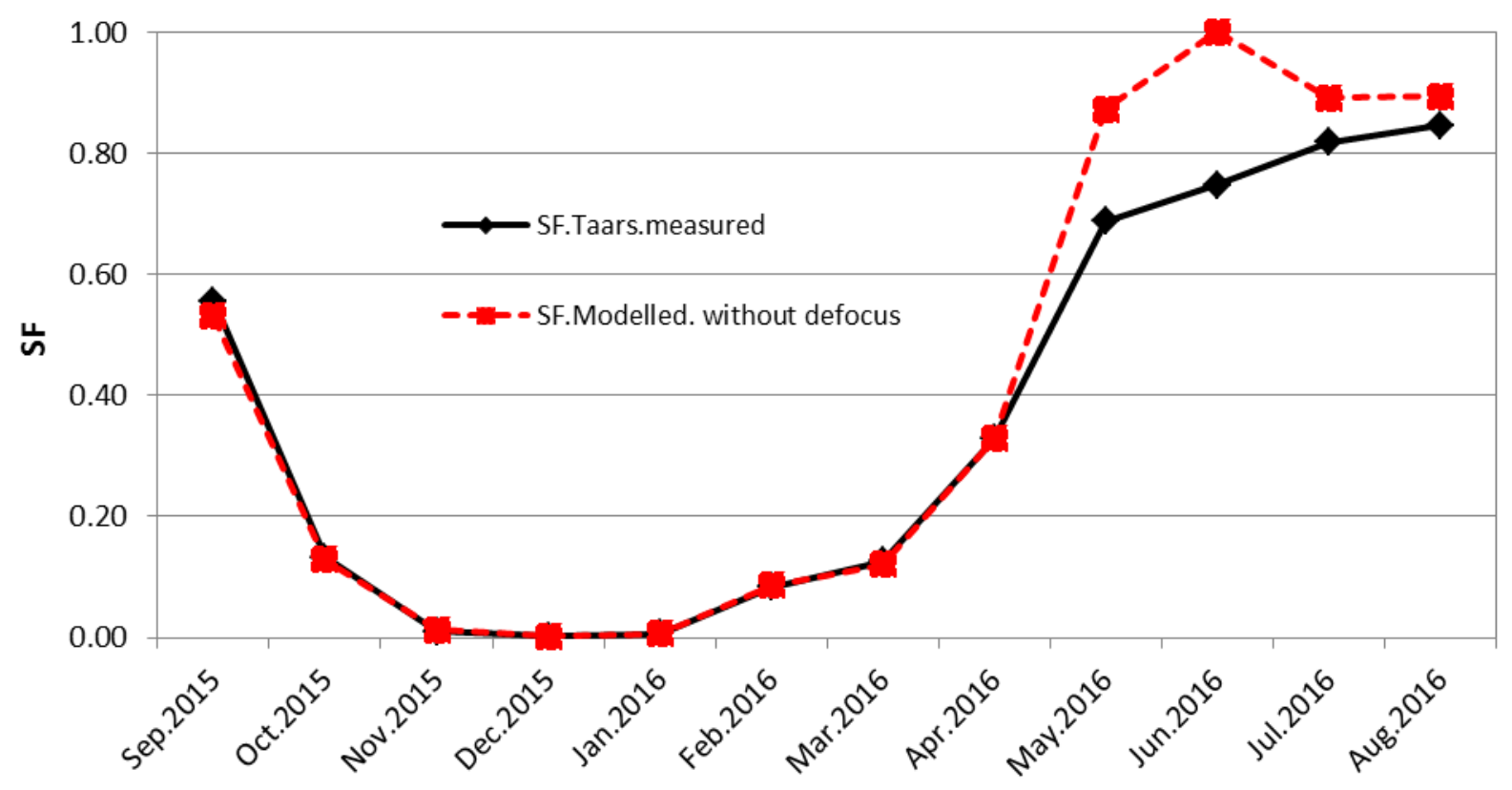

Fig.11. Solar fraction (SF) of Taars solar heating plant (Sep.2015-Aug.2016).

Table 5. Annual thermal performance of the Taars plant (Sep.2015-Aug.2016).

\begin{tabular}{ccl}
\hline Items & Value & Unit \\
\hline Heat demand, & 18460 & $\mathrm{MWh}$ \\
\hline Measured solar heat. FPC field & 448 & $\mathrm{kWh} / \mathrm{m}^{2}$ \\
\cline { 2 - 3 } & 2672 & $\mathrm{MWh}$ \\
\hline Modelled solar heat. FPC field & 448 & $\mathrm{kWh} / \mathrm{m}^{2}$ \\
\cline { 2 - 3 } & 2671 & $\mathrm{MWh}$ \\
\hline Measured solar heat. PTC field & 354 & $\mathrm{kWh} / \mathrm{m}^{2}$ \\
\cline { 2 - 3 } & 1431 & $\mathrm{MWh}$ \\
\hline Modelled solar heat. PTC field with defocus & 359 & $\mathrm{kWh} / \mathrm{m}^{2}$ \\
\hline $\begin{array}{c}\text { Modelled solar heat. PTC field without defocus } \\
\text { Measured solar heat. FPC+PTC }\end{array}$ & 1450 & $\mathrm{MWh}$ \\
\hline $\begin{array}{c}\text { Modelled solar heat. FPC+PTC with defocus } \\
\text { Modelled solar heat. FPC+PTC without defocus }\end{array}$ & 490 & $\mathrm{kWh} / \mathrm{m}^{2}$ \\
\hline $\begin{array}{c}\text { Measured solar fraction } \\
\text { Modelled solar fraction(PTC with defocus) }\end{array}$ & 41081 & $\mathrm{MWh}$ \\
\hline & 412 & $\mathrm{kWh} / \mathrm{m}^{2}$ \\
\hline & $22.2 \%$ & $\mathrm{kWh} / \mathrm{m}^{2}$ \\
\hline & $22.3 \%$ & - \\
\hline & $25.2 \%$ & - \\
\hline
\end{tabular}




\subsection{Utilized efficiency}

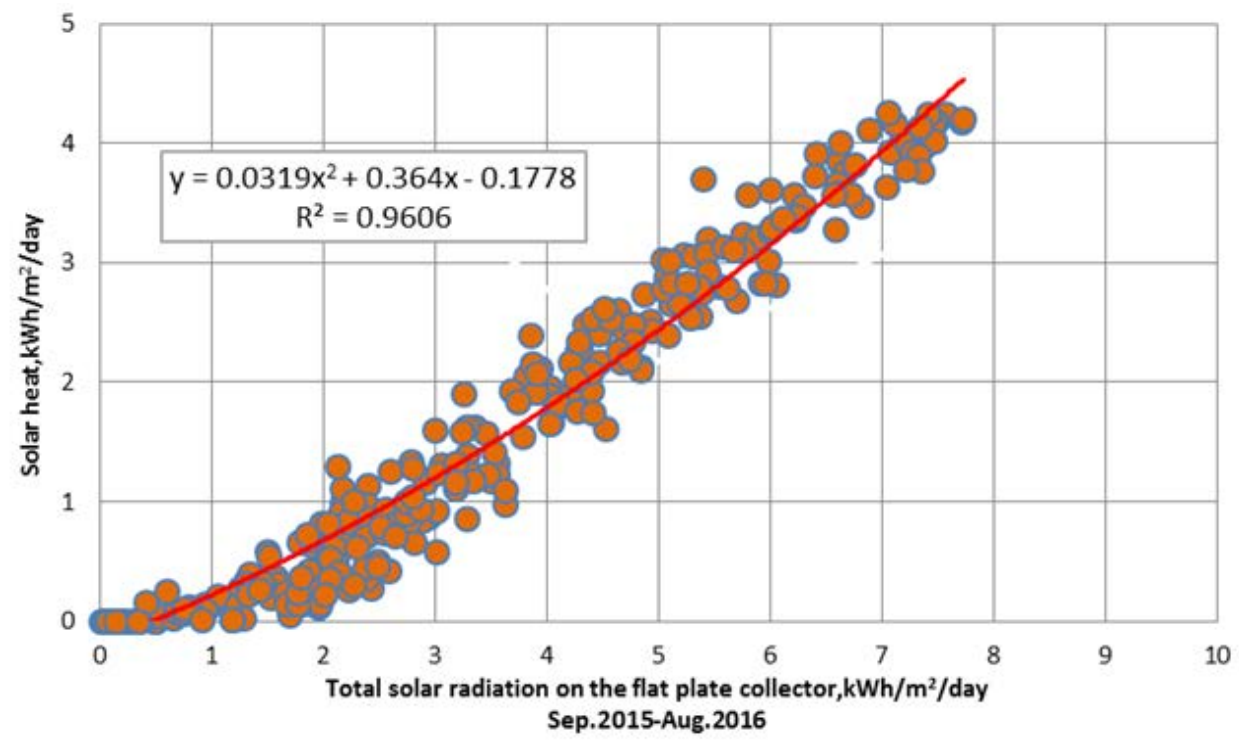

Fig.12. Measured daily solar heat as a function of total radiation on the flat plate collectors.

Figure 12 shows the measured daily solar heat of the flat plate collector field as a function of the total radiation on the tilted flat plate collectors. According to the fitting curve, the average daily efficiency of the flat plate collector field is about 0.48 . Max daily solar heat production of flat plate collector field is below $5 \mathrm{kWh} / \mathrm{m}^{2}$.

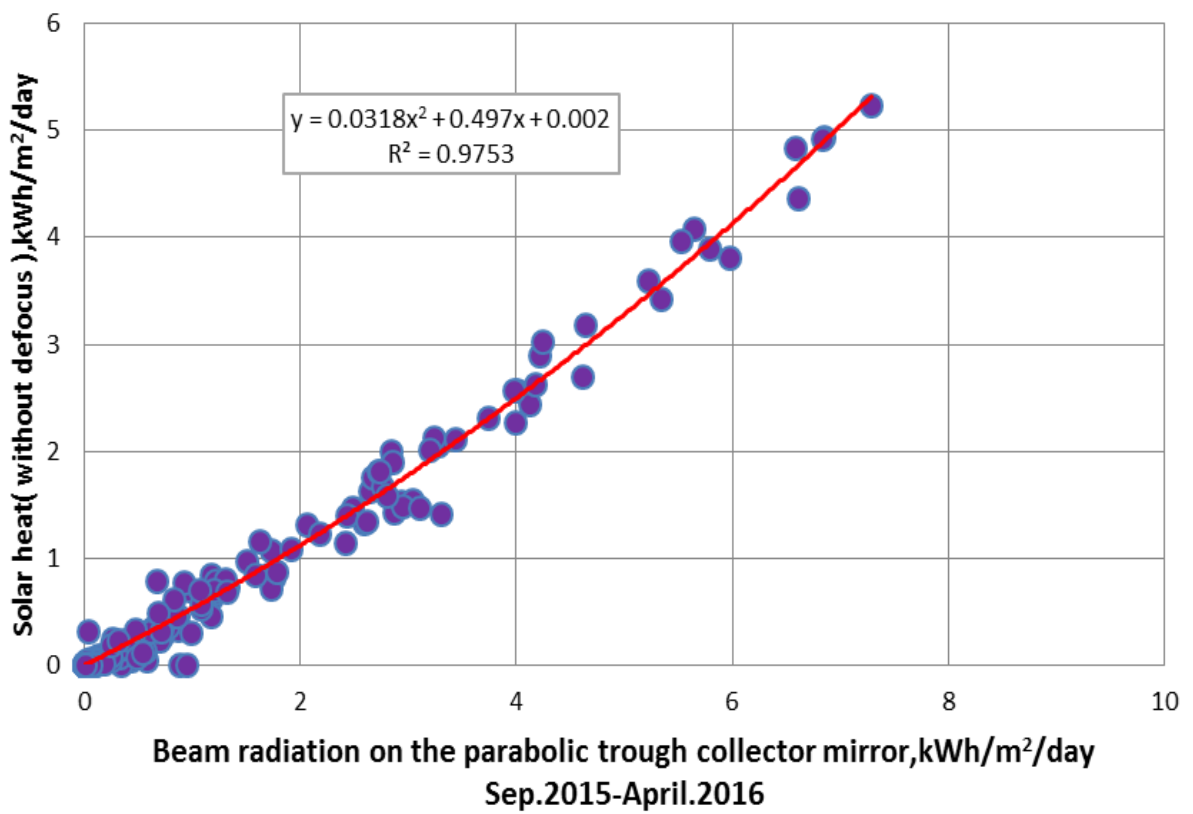

Fig.13. Measured daily solar heat as a function of daily beam radiation on the parabolic trough collectors.

The parabolic trough collectors were not put into defocus from Sep.2015 to Apr.2016. Figure 13 shows the measured daily solar heat without defocusing as a function of the beam radiation on the parabolic trough collectors from Sep.2015 to Apr.2016. The fitting curve illustrates that the average daily efficiency of the parabolic trough collector field based on the beam radiation on the parabolic trough collectors is about 0.66 . If the parabolic trough collectors work without defocusing in the summer, the daily efficiency in the summer would increase to about 0.70 and the parabolic trough collector field would produce more than $5 \mathrm{kWh} / \mathrm{m}^{2}$ per day in the sunny days. 


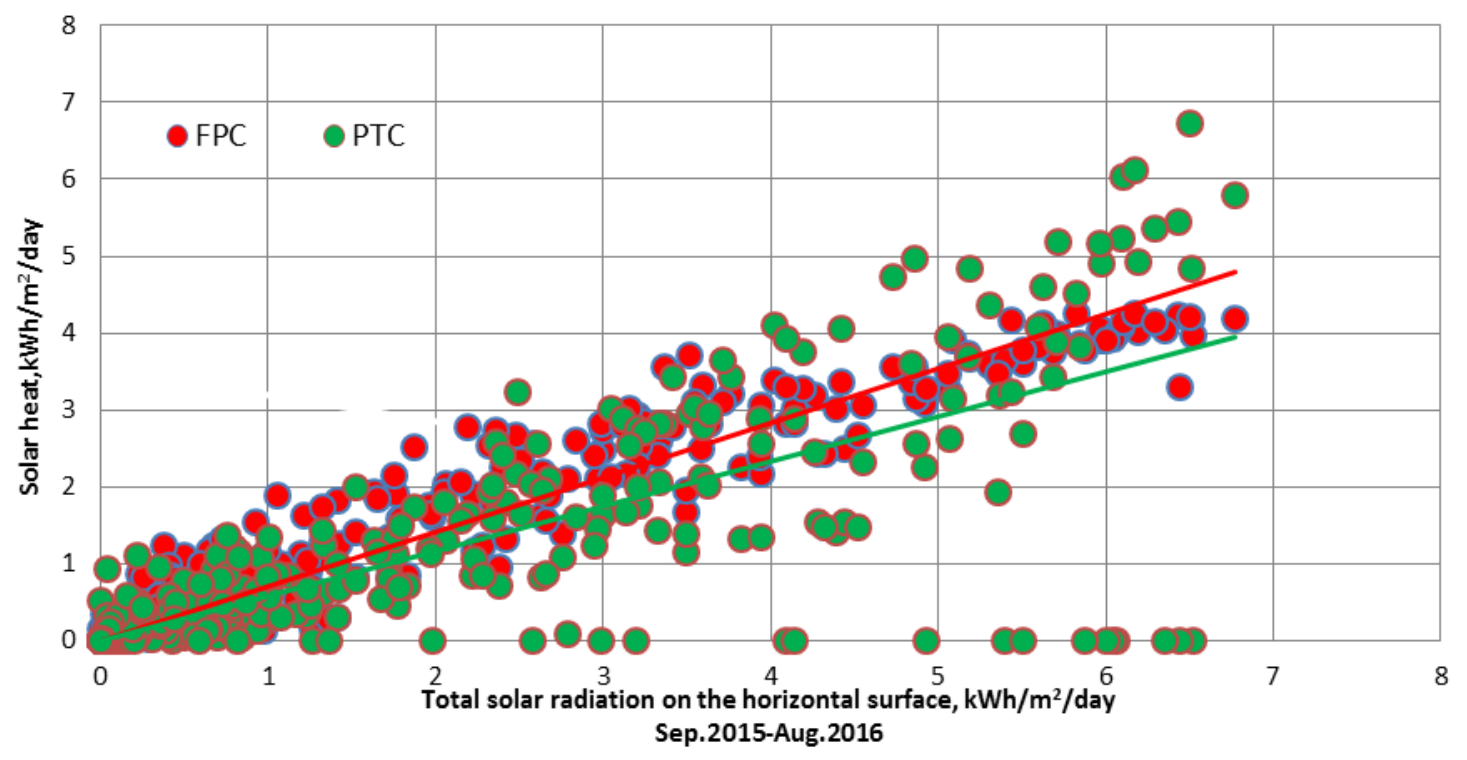

Fig.14. Measured daily solar heat as a function of daily global radiation for both collector fields.

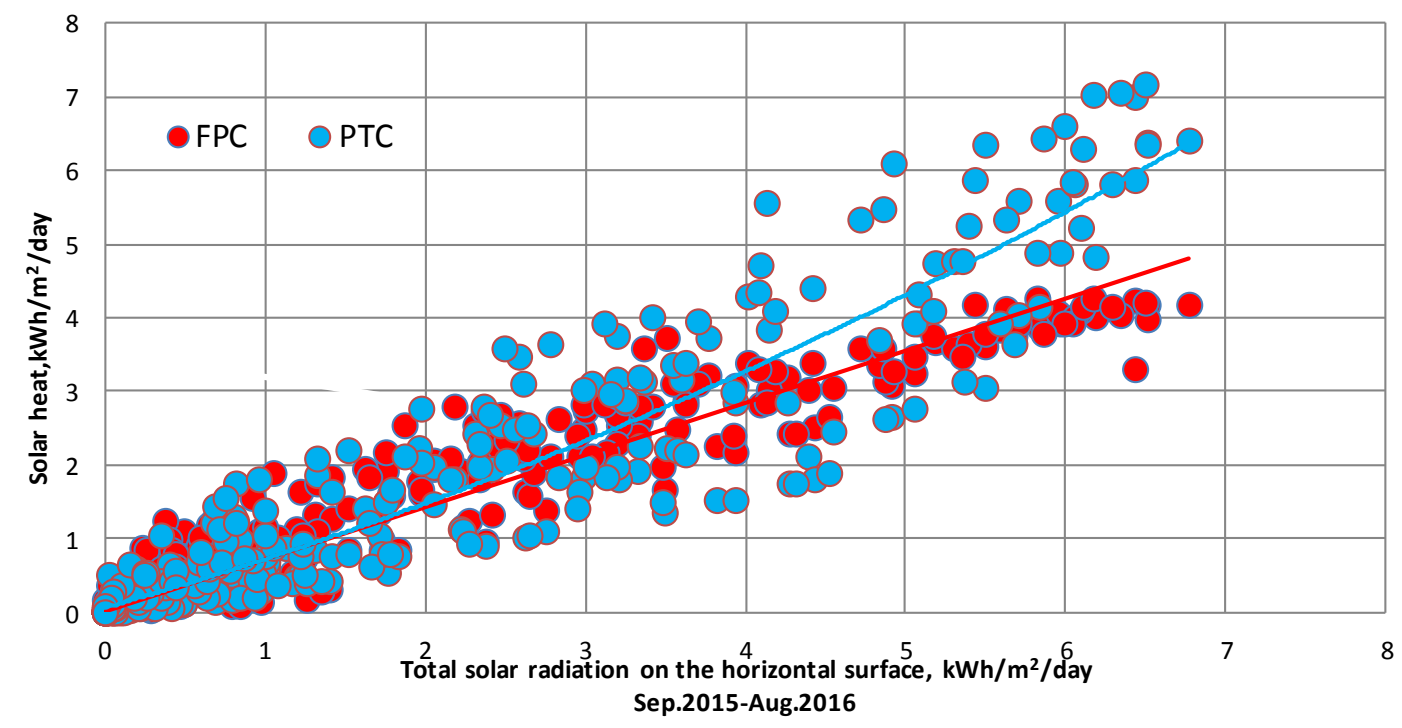

Fig.15. Modelled daily solar heat as a function of daily global radiation for both collector fields.

Both beam radiation and diffuse radiation influence thermal performance of the flat plate collector field, while the thermal performance of the parabolic trough collector field is mainly influenced by the beam radiation. To compare performances of both collector fields in a fair way, global radiation was chosen as a benchmark. Fig.14. shows measured daily solar heat for both collector fields as a function of the global radiation on the horizontal surface. The thermal performance of the parabolic trough collector field without defocus was modelled to investigate the maximum potential of parabolic trough collector field, as shown in Fig.15. It is seen that the thermal performance of the parabolic trough collector field was zero mainly because of defocus while the weather was sunny in Fig.14. In Fig.15, it is found that when the daily global radiation was lower than about $2 \mathrm{kWh} / \mathrm{m}^{2}$, the parabolic trough collector field did not perform better than the flat plate collector field. Furthermore, the parabolic trough collector field produced more heat than the flat plate collector field, when daily global radiation was higher than about $2 \mathrm{kWh} / \mathrm{m}^{2}$. 


\section{Discussions}

The Taars solar heating plant is the first large hybrid solar heating plant, which integrates both flat plate collectors and parabolic trough collectors to provide heat for a district heating network. The oversize of the flat plate collector field and low heat demand in the summer were the main reasons why the parabolic trough collectors were defocused in summer periods. Potential of the Taars plant in the DRY (Design Reference Year [42]) is shown in this section.

Figure 16 shows monthly measured global radiation on horizontal in the Taars plant and global radiation of the DRY of Northern Jutland [42]. Table 6 shows the summary of weather conditions in Taars (Sep.20105Aug.2016) and in the DRY. The measured global radiation in the Taars solar heating plant from Sep.2015 to Aug.2016 is $980 \mathrm{kWh} / \mathrm{m}^{2}$, while that of DRY is $1030 \mathrm{kWh} / \mathrm{m}^{2}$. It is found that there was less sun shine from Sep.2015 to Aug.2016 compared to DRY.

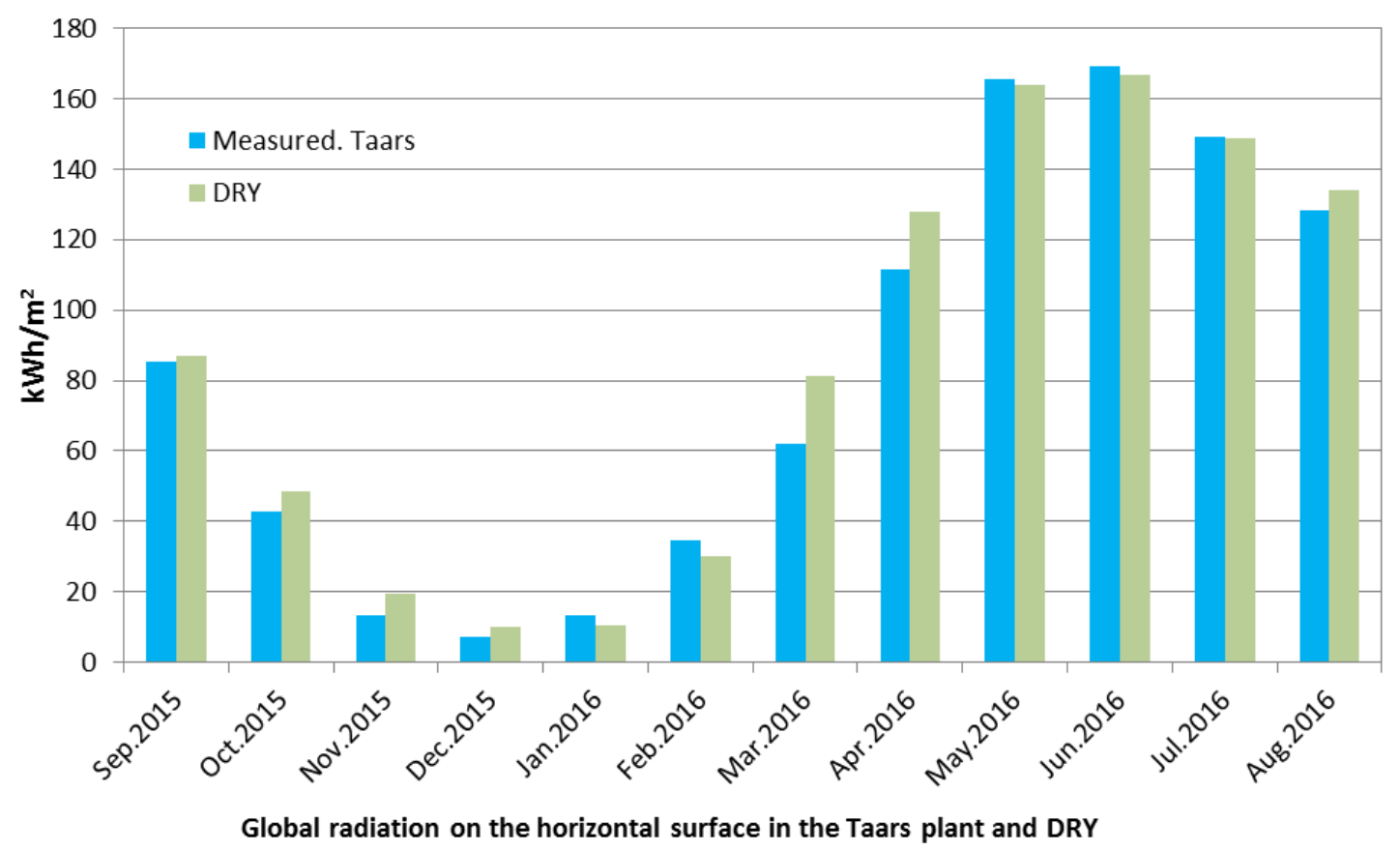

Fig.16. Monthly global radiation in the Taars plant and in the DRY.

Table 6. Weather parameters measured in Taars (Sep.2015-Aug.2016) and in the DRY.

\begin{tabular}{ccc}
\hline DNI, $\mathrm{kWh} / \mathrm{m}^{2}$ & 990 & Sep.2015-Aug.2016 \\
& 1150 & DRY \\
\hline Total radiation on tilted FPC plane, & 1170 & Sep.2015-Aug.2016 \\
$\mathrm{kWh} / \mathrm{m}^{2}$ & 1295 & DRY \\
\hline \multirow{2}{*}{ Global horizontal radiation, $\mathrm{kWh} / \mathrm{m}^{2}$} & 980 & Sep.2015-Aug.2016 \\
& 1030 & DRY \\
\hline \multirow{2}{*}{ Heat demand, MWh } & 18460 & Sep.2015-Aug.2016 \\
& 21660 & DRY \\
\hline
\end{tabular}




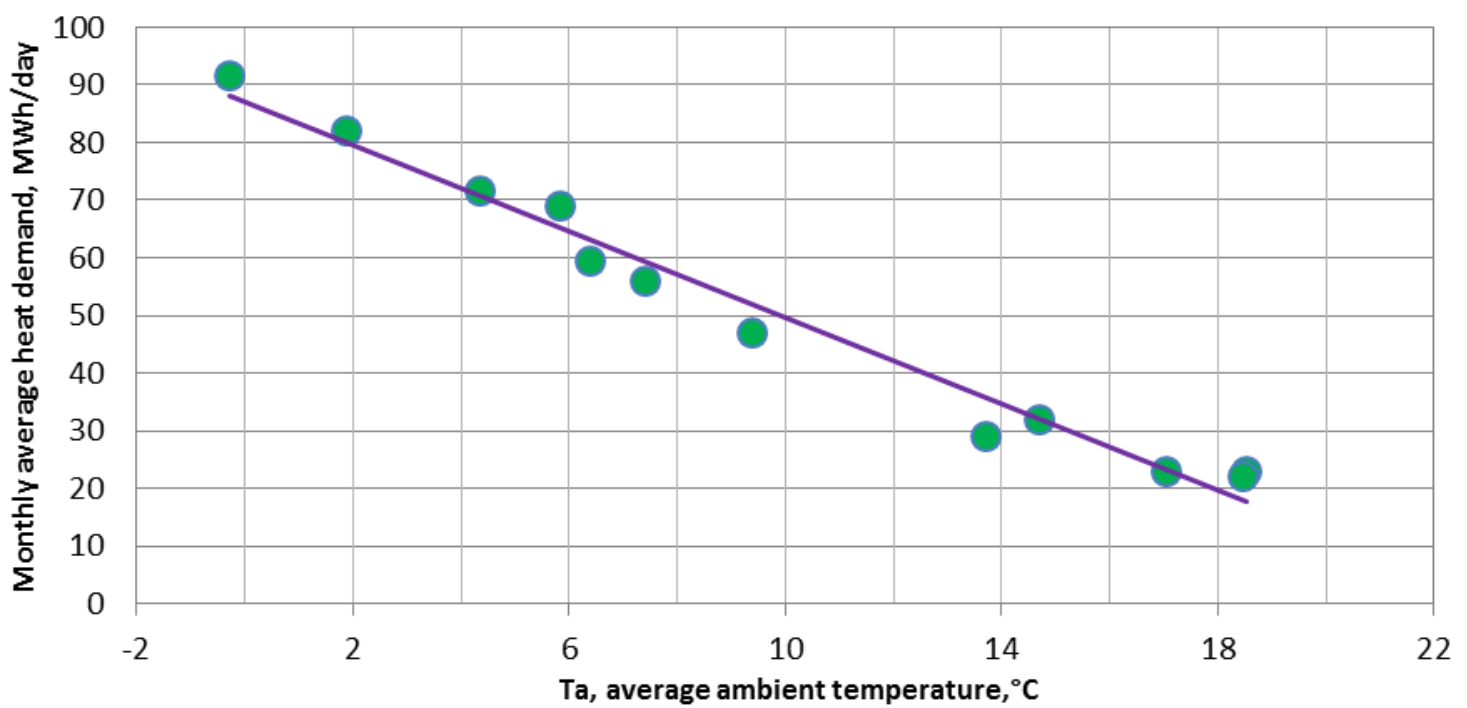

Fig.17. Measured monthly heat demand (average value per day) as a function of average ambient temperature of Taars solar heating plant (Aug.2015-Aug.2016).

Figure 17 shows the relation between monthly heat demand (average value per day) and average ambient temperature from Sep.2015 to Aug.2016. The heat demand in the DRY in Table 7 is calculated by the fitting curve in Figure 17 and the average ambient temperatures of the DRY. The heat demand of the Taars solar heating plant in the DRY is a bit higher than measured values from Sep.2015-Aug.2016.

Table 7. Calculated annual thermal performance of

Taars solar heating plant in the DRY for Northern Jutland.

\begin{tabular}{cc}
\hline Item & Value \\
\hline \multirow{2}{*}{ Solar heat.FPC field } & $510 \mathrm{kWh} / \mathrm{m}^{2}$ \\
& $3040 \mathrm{MWh}$ \\
\hline \multirow{2}{*}{ Solar heat.PTC field } & $530 \mathrm{kWh} / \mathrm{m}^{2}$ \\
& $2140 \mathrm{MWh}$ \\
\hline Heat demand & $21590 \mathrm{MWh}$ \\
Solar fraction & $24 \%$ \\
\hline
\end{tabular}

Table 7 also shows calculated annual thermal performance of the Taars solar heating plant in the DRY, calculated by DTU Excel tool (Dragsted and Furbo, 2012) [29]. Mean solar collector fluid temperatures of the flat plate collector field and the parabolic trough collector field were assumed to be $55^{\circ} \mathrm{C}$ and $80^{\circ} \mathrm{C}$ respectively based on the measurements. The parabolic trough collector field is assumed to work without defocus. The potential thermal performance of the Taars solar heating plant in the DRY is $5180 \mathrm{MWh}$, while the heat demand in the DRY is 21590 MWh. Furthermore, the solar fraction is 24\%. Table 7 also illustrates that the thermal performance of flat plate collectors can be higher than $500 \mathrm{kWh} / \mathrm{m}^{2}$ under Danish climate conditions when the flat plate collectors work at low operation temperatures like $55^{\circ} \mathrm{C}$ in such a combined solar heating plant.

The investigations have shown that it is very important to size the collector areas of both the flat plate collectors and parabolic trough collectors in such a way that oversizing is avoided, so that the parabolic trough collector field is not put out of focus in the summer. An increase of the heat load of the district heating network in the future can increase thermal performance of the plant. Furthermore, a large heat storage could also be helpful to harvest the advantages of parabolic trough collectors in the summer. The advantages of the hybrid solar heating plants are that the flat plate collector field produces about $60 \mathrm{kWh} / \mathrm{m}^{2}$ one year more than the normal solar heating plants with only flat plate collectors, and the defocus of the parabolic trough collectors increases the flexibility of the solar heating plants in the whole energy supply system. This study not only demonstrates the feasibility and potential of the hybrid solar heating plants at the high latitude with low solar 
radiation resource, but also introduces a novel design concept of higher efficient solar heating plants for the high solar radiation area

\section{Conclusions and future work}

Both measured and simulated annual thermal performances of the Taars solar heating plant were analysed for the whole year from September 2015 to August 2016. The thermal performance of the Taars solar heating plant in the DRY for the northern part of Jutland was also investigated. These findings can be used in the design of new large-scale solar district heating plants in the near future. The conclusions are as follows:

The solar fraction of the Taars solar heating plant was 22.2\% during the period from Sep.2015 to Aug.2016. If the parabolic trough collector field had not been defocused, the total thermal performance would have increased from $4100 \mathrm{MWh}$ to $4650 \mathrm{MWh}$, that is from $410 \mathrm{kWh} / \mathrm{m}^{2}$ to $465 \mathrm{kWh} / \mathrm{m}^{2}$ and the solar fraction would have reached $25.2 \%$.

Potential annual thermal performance of the Taars solar heating plant in the DRY for northern Jutland could reach $5180 \mathrm{MWh}\left(518 \mathrm{kWh} / \mathrm{m}^{2}\right)$ and a solar fraction of $24 \%$ if defocusing of the parabolic trough collectors is avoided.

Further studies on the optimization of the thermal performance and control strategy of the hybrid solar district heating plant are required to formulate comprehensive design rules for such hybrid solar heating plants.

\section{Acknowledgements}

Special thanks are expressed to Aalborg CSP A/S (Andreas Zourellis) for the information provided. The first author also appreciates the financial support of China Scholarship Council for the PhD study (No.201506120074). This work is also a part of an EUDP (Energy Technology Development and Demonstration) project financed by the Danish Energy Agency.

\section{Nomenclature}

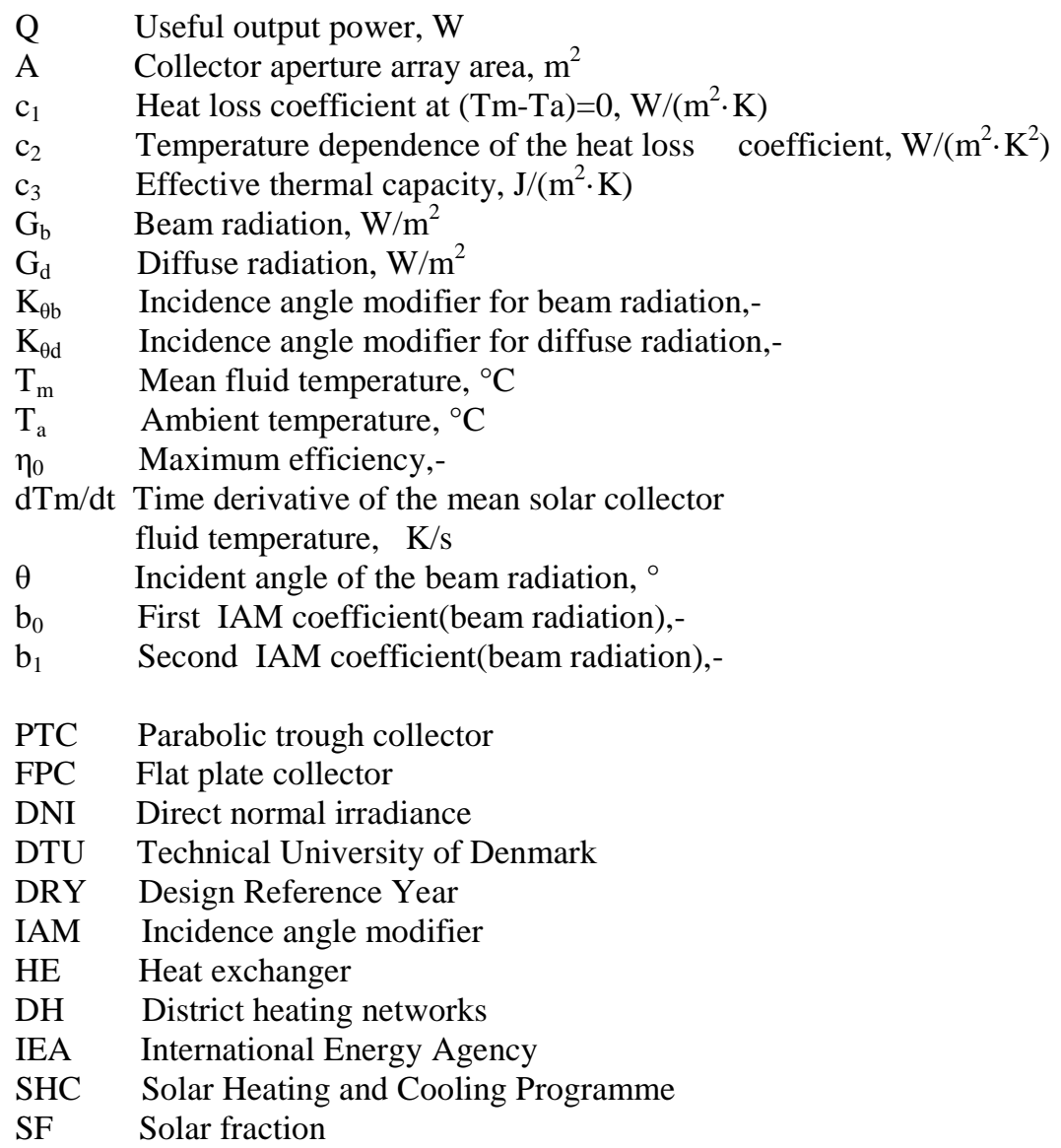




\section{References}

[1] Z. Liu, W. Xu, C. Qian, X. Chen, and G. Jin, "Investigation on the feasibility and performance of ground source heat pump (GSHP) in three cities in cold climate zone, China,” Renew. Energy, vol. 84, pp. 89-96, 2015.

[2] Z. Tian, S. Zhang, H. Li, Y. Jiang, J. Dong, B. Zhang, and R. Yi, "Investigations of Nearly (net) Zero Energy Residential Buildings in Beijing,” Procedia Eng., vol. 121, pp. 1051-1057, 2015.

[3] C. A. Balaras, A. G. Gaglia, E. Georgopoulou, S. Mirasgedis, Y. Sarafidis, and D. P. Lalas, "European residential buildings and empirical assessment of the Hellenic building stock, energy consumption, emissions and potential energy savings,” Build. Environ., vol. 42, no. 3, pp. 1298-1314, 2007.

[4] J. Deng, Z. Tian, J. Fan, M. Yang, S. Furbo, and Z. Wang, “Simulation and optimization study on a solar space heating system combined with a low temperature ASHP for single family rural residential houses in Beijing," Energy Build., vol. 126, pp. 2-13, 2016.

[5] D. Buoro, P. Pinamonti, and M. Reini, "Optimization of a Distributed Cogeneration System with solar district heating,” Appl. Energy, vol. 124, pp. 298-308, Jul. 2014.

[6] V. Tulus, D. Boer, L. F. Cabeza, L. Jimenez, and G. Guillen-Gosalbez, "Enhanced thermal energy supply via central solar heating plants with seasonal storage: A multi-objective optimization approach,” Appl. Energy, vol. 181, pp. 549-561, 2016.

[7] U. Persson and S. Werner, "Heat distribution and the future competitiveness of district heating," Appl. Energy, vol. 88, no. 3, pp. 568-576, Mar. 2011.

[8] S. Furbo, J. Fan, B. Perers, W. Kong, D. Trier, and N. From, “Testing, Development and Demonstration of Large Scale Solar District Heating Systems,” Energy Procedia, vol. 70, pp. 568-573, 2015.

[9] M. Fish, M. Guigas, and J. Dalenback, “A review of large-scale solar heating systems in Europe,” Sol. Energy, vol. 63, no. 6, pp. 355-66, 1998.

[10] P. Reiter, H. Poier, and C. Holter, "BIG Solar Graz: Solar District Heating in Graz - 500,000 m2 for 20\% Solar Fraction,” Energy Procedia, vol. 91, pp. 578-584, 2016.

[11] Werner Weiss, Monika Spörk-Dür, Franz Mauthner, Solar Heat Worldwide-Global Market Development and Trends in 2016-Detailed Market Figures 2015 (2017 version). http://www.iea-shc.org/solar-heat-worldwide, 2017.

[12] Danish District Heating Association, “Solvarmedata,” www.solvarmedata.eu., 2017.

[13] F. Bava and S. Furbo, “A numerical model for pressure drop and flow distribution in a solar collector with horizontal U-connected pipes,” Sol. Energy, vol. 134, pp. 264-272, 2016.

[14] PlanEnergi, "planenergi,” http://planenergi.eu/activities/fjernvarme/solar-heating/, 2017. [Online]. Available: 2017.

[15] IEA, “IEA-SHC Task 49,” http://task49.iea-shc.org/publications, 2016. [Online]. Available: 2017.

[16] E. Frank, H. Marty, L. Hangartner, and S. Minder, "Evaluation of measurements on parabolic trough collector fields for process heat integration in Swiss dairies,” Energy Procedia, vol. 57, pp. 2743-2751, 2014.

[17] R. Silva, M. Perez, and A. Fernandez-Garcia, "Modeling and co-simulation of a parabolic trough solar plant for industrial process heat,” Appl. Energy, vol. 106, pp. 287-300, 2013.

[18] R. Silva, M. Berenguel, M. Perez, and A. Fernandez-Garcia, "Thermo-economic design optimization of parabolic trough solar plants for industrial process heat applications with memetic algorithms,” Appl. Energy, vol. 113, pp. 603-614, 2014.

[19] I. Ben Hassine, M. C. Sehgelmeble., R. Soll, and D. Pietruschka, "Control Optimization through Simulations of Large Scale Solar Plants for Industrial Heat Applications,” Energy Procedia, vol. 70, no. 0, pp. 595-604, 2015.

[20] M. Larcher, M. Rommel, A. Bohren, E. Frank, and S. Minder, "Characterization of a parabolic trough collector for process heat applications,” Energy Procedia, vol. 57, pp. 2804-2811, 2014.

[21] O. Kizilkan, A. Kabul, and I. Dincer, "Development and performance assessment of a parabolic trough solar collector-based integrated system for an ice-cream factory,” Energy, vol. 100, pp. 167-176, 2016.

[22] B. Zou, J. Dong, Y. Yao, and Y. Jiang, “An experimental investigation on a small-sized parabolic trough solar collector for water heating in cold areas,” Appl. Energy, vol. 163, pp. 396-407, Feb. 2016.

[23] D. Krueger, A. Heller, K. Hennecke, K. Duer, S. Energietechnik, D. Zentrum, and L. Höhe, "Parabolic Trough Collectors for District Heating Systems At High Latitudes,” in Proceedings of Eurosun, 2000.

[24] E. M. A. Mokheimer, Y. N. Dabwan, M. A. Habib, S. A. M. Said, and F. A. Al-Sulaiman, "Development and assessment of integrating parabolic trough collectors with steam generation side of gas turbine cogeneration systems in Saudi Arabia,” Appl. Energy, vol. 141, pp. 131-142, 2015.

[25] M. Eck and T. Hirsch, "Dynamics and control of parabolic trough collector loops with direct steam generation," Sol. Energy, vol. 81, no. 2, pp. 268-279, 2007.

[26] T. E. Boukelia, O. Arslan, and M. S. Mecibah, "ANN-based optimization of a parabolic trough solar thermal power plant,” Appl. Therm. Eng., vol. 107, pp. 1210-1218, 2016.

[27] P. A. González-Gómez, F. Petrakopoulou, J. V. Briongos, and D. Santana, “Cost-based design optimization of 
the heat exchangers in a parabolic trough power plant,” Energy, vol. 123, pp. 314-325, 2017.

[28] N. B. Desai and S. Bandyopadhyay, "Optimization of concentrating solar thermal power plant based on parabolic trough collector,” J. Clean. Prod., vol. 89, pp. 262-271, 2015.

[29] T. E. Boukelia, O. Arslan, and M. S. Mecibah, "Potential assessment of a parabolic trough solar thermal power plant considering hourly analysis: ANN-based approach,” Renew. Energy, vol. 105, pp. 324-333, 2017.

[30] D. D. Nation, P. J. Heggs, and D. W. Dixon-Hardy, "Modelling and simulation of a novel Electrical Energy Storage (EES) Receiver for Solar Parabolic Trough Collector (PTC) power plants,” Appl. Energy, vol. 195, pp. 950-973, 2017.

[31] M. Bortolato, S. Dugaria, and D. Del Col, "Experimental study of a parabolic trough solar collector with flat bar-and-plate absorber during direct steam generation,” Energy, vol. 116, pp. 1039-1050, 2016.

[32] T. E. Boukelia, M. S. Mecibah, B. N. Kumar, and K. S. Reddy, "Optimization, selection and feasibility study of solar parabolic trough power plants for Algerian conditions,” Energy Convers. Manag., vol. 101, pp. 450-459, 2015.

[33] D. Kumar and S. Kumar, "Year-round performance assessment of a solar parabolic trough collector under climatic condition of Bhiwani, India: A case study,” Energy Convers. Manag., vol. 106, pp. 224-234, 2015.

[34] A. CSP, “Aalborg CSP,” http://www.aalborgcsp.com/, 2016. .

[35] B. Perers, S. Furbo, Z. Tian, J. Egelwisse, F. Bava, and J. Fan, "Tårs 10000 m2 CSP + Flat Plate Solar Collector Plant - Cost-Performance Optimization of the Design,” Energy Procedia, vol. 91, pp. 312-316, 2016.

[36] Arcon-Sunmark, “Arcon-Sunmark," http://arcon-sunmark.com/products. [Online]. Available: Mar.2017.

[37] B. Perers, S. Furbo, and J. Dragsted, "Thermal performance of concen- trating tracking solar collectors," DTU.Report, vol. 292, no. August, 2013.

[38] SP, “Technical Research Institute of Sweden,” https://www.sp.se/en/Sidor/default.aspx, 2016.

[39] SolarKeyMark, "Solar Keymark Certification," http://www.solarkeymark.dk/, 2017.

[40] Z. Tian, "Analysis and validation of a quasi-dynamic model for a solar collector field with flat plate collectors and parabolic trough collectors in series for district heating," Manuscript, 2017.

[41] TRNSYS, “TRNSYS 17-a TRaNsient SYstem Simulation program -Volume 4 Mathematical Reference,” http://web.mit.edu/parmstr/Public/TRNSYS/04-MathematicalReference.pdf. [Online]. Available: June 2017.

[42] Janne Dragsted;Simon Furbo, "Solar radiation and thermal performance of solar collectors for Denmark," DTU Rep., vol. 275, 2012. 